\title{
THE HISTORICAL BACKGROUND OF THE SLOVAK PRESS IN THE USA
}

It was the Slovak-American press that had unified the Slovak community in the USA. It had represented a relevant source of information about the Slovak community life as well as about the situation back home in Europe. The preservation of Slovak cultural heritage in a specific heterogeneous environment helped to awaken Slovak interest in national issues and encouraged the Slovak nation to speak up for their rights.

Keywords: Slovak immigration, USA, Slovak-American press.

\section{Introduction}

The term "Slovak-American press" requires an attempt to account for a concept of the notion "the Slovakicist document" within the concept of a library document. The Slovakicist document is defined as a library document written in Slovak or related to Slovakia or the Slovak nation issued in or outside the Slovak Republic whose author or authors are of Slovak nationality or Slovak roots [1]. The press of Slovak Americans represents highly valuable documentary heritage which contributes to a community identity and helps to preserve the Slovak identity and nationalism in or outside the Slovak minority living in the USA. The section of Book Culture History of the Slovak National Library in Martin represents the main sector for research and development of book collections, both territorial and extraterritorial Slovak related prints.

\section{The historical background of the Slovak press in the USA}

\subsection{The first Slovak Fraternal Organizations}

The well-known source book about the first Slovak institutions abroad is the one written by a great Slovak historian Konstantin Culen "The History of Slovaks in America", 1942 [2]. A current historical researcher, Marian Mark Stolarik, the professor at the Cleveland State University of Minnesota, whose publications include valuable information about the beginnings of the first Slovak organizational, cultural and political activities, argues that the cornerstone of Slovak cultural heritage preservation is built

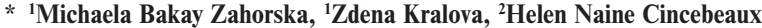
'Faculty of Humanities, University of Zilina, Slovakia

${ }^{2}$ Slovak Heritage and Folklore Society International, Rochester, USA

E-mail: michaela.bakayzahorska@fhv.uniza.sk
}

on three essential pillars: parish churches, press and fraternal organizations.

Even in the early years of settlement in North America, the ethnic minorities had learnt the principles of collectivism to deal with the hard time they came across in a new world. In need of help in case of illness, fatal or serious injury, there were no social services provided by American employers. The beginnings of the first societies date back to the early $17^{\text {th }}$ century and had primarily social character. It was not Slovaks but Scottish immigrants who set up the first so called self-help organizations that provided the essential services to their members. Later on they were followed by other ethnic groups - Polish, Irish and Czech [3].

Catholic religious traditions supported the Slovak intentions to gather for both their protection and loyalty. Soon, they formed their own institutions that helped them to survive in a capitalist economy. Their primary intention was to follow their social and national program, to offer their members help in need, to assist in parish churches, education centre and first press institution establishment. M. M. Stolarik [3] reports about fifty beneficial societies that had been established by 1890 , twenty-five of them in Pennsylvania. Persi Uherszko-Szlovenszky v Nyemoczi Podporujuci Szpolek is reported as the first fraternal institution founded in 1883 in New York [2]. Soon, more than 40 fraternal associations had been formed in the northeastern and midwestern part of the United States. Many priests had left Austrian-Hungarian Empire to help to build the intellectual life in Slovak communities in the USA. By 1896 the scattered regional societies were affiliated and transformed into full-fledge insurance companies.

The most influential The National Slovak Society was established in Pittsburgh in 1890. The organization was led 
by Peter V. Rovnianek who was the father of the first Slovak daily newspaper in Pittsburgh, Amerikansko-Slovenske Noviny [4]. The rivalry national body, The First Catholic Slovak Union was established by Reverend Stefan Furdek in February 1890. The need for one united organization rose. This fact lead to an ideological clash between Furdek and Rovnianek in which the Slovak American press played an important role. While Furdek's idea was to build one primarily religious institution, Rovnianek called for the national one [2]. Though they belonged to the opposing religious divisions, they used their editorial skills to gain new members.

The abolition of Matica Slovenska together with anti-Slavic activities organized by Hungarian authorities resulted in the birth of Matica Slovenska in America in Chicago on $26^{\text {th }}$ September 1893 headed by Stefan Furdek. The aim of the institution was to take care of Slovak cultural and national life both in America and back home [2]. But the ideological conflict between Rovnianek and Furdek continued and resulted in the establishment of the Matica Slovenska rivalry institution called Majak in Pittsburgh in 1894. It issued the literary magazine Majak [2]. The conflict continued and resulted in the dissolution of the institution.

The formation of the Slovak League of America in 1907 meant a breakthrough in the Slovak national and political activities. It was this institution that managed to affiliate several rival fraternalbenefit associations under one strong institution. The League helped to declare the common state of Czech and Slovaks on the federation basis by signing the Cleveland Agreement on 22 October 1915 followed by the Pittsburgh Agreement on 31 May 1918. It was the sign that Slovak Americans were strong enough to control their activities not only in the USA but, which is more important, also in Europe.

The Slovak-fraternal organizations represented a radical change in thinking and allowed the Slovak communities to interfere with the political situation even in their home land in Europe during the years of the formation of the first independent Slovak Republic. Slovak Americans believed in the rights of Slovaks to self-determination also during the World War II and the Slovak League of America supported the idea of the independent Slovakia at the Conference in San Francisco in 1945. But the discontent with the post war situation resulted in the next wave of immigration into the USA.

\subsection{The beginnings of Slovak press activities in the USA}

It is the press that acts as a great background material on Slovak American community life. It was formed as the reaction to the lack of relevant and unbiased international and local news for Slovak workers. It reflected a harsh battle between the major Slovak American religious groups. It called for liberation movement back home in Austria-Hungary, and expressed the
Slovak American attitude to a postwar Czechoslovakia and independent Slovakia. The history of the first Slovak press activities in the USA dates back to 1885 . According to L. Bartalska [5] there had been about 250 Slovak daily, weekly and monthly newspapers issued mostly in North America since then and their number had culminated over the years.

The respected historian on this subject, K. Culen [2] classified the Slovak American publications into nine categories (Fig. 1) and listed about 246 titles in his work from which M. M. Stolarik left out about 39 titles but added another 13. Subsequently, he arrived at the total number of 220 releases [6]. What is more, M. M. Stolarik provides a valuable demographic profile and a rate of press survival in his work. "Twenty-six of all Slovak-American newspapers published since 1885 have originated in Pittsburgh region and 41 percent in the Commonwealth of Pennsylvania. 50 percent of all Slovak-American newspapers lasted less than two years and 66 percent lasted less than seven years" [6].

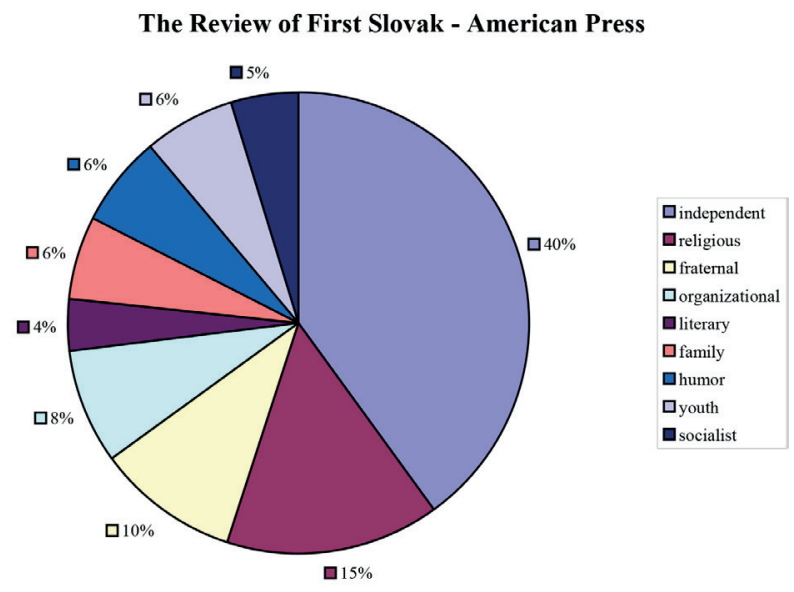

Fig. 1 Classification of the first Slovak press in the USA

\section{The first Slovak-American editors}

One of the first editors of the articles for Slovak communities in the USA was Janko Jesensky. The first issue of his Bulletin was released in 1885 in Pittsburgh, Pennsylvania. At that time the Bulletin was not printed but written in ink. The Bulletin appeared as one of the first independent, general news press that was distributed among American Slovaks in the 19th century [5]. The first printed Slovak newspaper was called the Amerikanszko-Szlovenszke Noviny that appeared in Pittsburgh in 1886. The editor of the newspaper was Julius Wolf who teamed up with Janko Jesensky. The newspaper was written in the eastern Slovak dialect which called for the radical change. In 1889 Peter V. Rovnianek became a new editor of the newspaper. P. V. Rovnianek published the AmerikanszkoSzlovenszke Noviny in the central Slovak dialect and renamed it to the Amerikansko-Slovenske Noviny. This act was a breakthrough in 
the Slovak American press activities. Since then all Slovak American press had adopted the nationalist philosophy [6].

According to P. Holestiak [7], in 1910 the weekly, the Amerikansko-Slovenske noviny, recorded the highest circulation of all compatriotic newspapers (40,000 issues). At the beginning of the 20th century the Amerikansko-Slovenske Noviny folded. Soon after, Peter V. Rovnianek established his new newspaper called Slovensky Dennik. The Slovak in America has been the longest-lasting Slovak newspaper issued in northern America. The newspaper was founded in 1889 by a fraternal leader Anton S. Ambrose as the worker's weekly in Plymouth, Pennsylvania [6]. The newspaper has been one of the most influential and significant publications in Slovak American national and political battle over the centuries. What is more, the newspaper is published in the Slovak language up to now.

Later on almost all religious denominations published their own periodicals. M. M. Stolarik [6] reports the Catholic News as the earliest religious weekly of thirty-three religious periodicals published between 1889 and 1984. The publisher of the periodical was Reverend Ignac Jaskovic from Hazelton, Pennsylvania. The Witness was reported as the official monthly released by the Synod of Slovak Evangelical Lutheran Churches in America in Pittsburgh. The Slovak Evangelical Zion Synod started to publish the Good Shepherd as a rival publication to the Zion of Pittsburgh, 1920 [6].

Besides the editors of the first independent and religious Slovak press in the USA, the fraternal communities worked on their own newspapers or bulletins for their members. These newspapers reported on their activities and agitated for their new members. The press represented one of the most influential factors of all Slovak fraternal societies in America since it acted as their official organ reflecting their religious and national orientation.

It is important to mention the most significant publications that supported the Slovak national identity. The first weekly fraternal publication has remained active over the centuries up to the present, was the Catholic Jednota founded by Reverend S. Furdek in 1891 in Cleveland. The newspaper brought both domestic and international news, news about the activities of the fraternal benefit organization The First Catholic Slovak Union. Besides the others, The National Slovak Society issued the National News as their official weekly and a rival to Jednota in 1910. The First Catholic Slovak Ladies Union, settled in Cleveland, Ohio, released the Women's Union and later a magazine called the Fraternally Yours as their official organ [6]. The weekly Slovak Falcon was issued in Passaic, New Jersey together with the weekly the Catholic Falcon that was published by the Slovak Catholic Sokol. The Pennsylvania Catholic Slovak Union's official organ was The Brotherhood, and the Slovak Herald was the official weekly of the Slovak Evangelical Union headquartered in Pittsburgh. The Slovak Gymnastic Union Sokol settled in New Jersey. The organization issued the weekly Slovak
Falcon which was pro-Czechoslovak even though together with the Slovak Calvin which was an official publication of the Slovak Calvin Presbyterian Union.

Besides the above mentioned publications, M. M. Stolarik [6] surveyed eight literary journals, for instance the Lighthouse, and only thirteen family magazines with short longevity. In his work M. M. Stolarik mentions fourteen humor magazines, for example The Demon. The Demon was published from 1896 to 1912. Seventeen organizational publications were connected mostly with workers' organizations such as the Worker or the Progressive Union. Slovak Americans published about fourteen youth and student periodicals that were issued mainly as a monthly supplement to their weekly publications, for example the Youth Folks or the Friend of Children [6].

L. Bartalska [5] reports that since the 1960s the number of Slovak-American periodicals has declined. It is the result of a new formation of immigrants who moved out from the original settlements of their predecessors in seek of new job opportunities. This trend has lead to a huge assimilation process.

\section{Current situation}

The turbulent years throughout the history have changed the way of life of the Slovak community in the USA. A new generation of Slovak-Americans living in North America has adopted bi-national identity that allowed them to scatter all round the United States. The globalization and huge assimilation process resulted in a prevalent use of the English language in a new generation community of Slovaks living in the USA. It allows them to find better job opportunities in their area. This trend calls for the need to strengthen the ways of communication among people in a minority community in order to preserve their national identity, ethnicity and their language [8]. The language and patriotism awareness are one of the most essential elements of the national identity preservation. What is more, these elements represent an important link between the Slovaks living abroad and those in Slovakia.

The number of Slovak press releases in the USA has dramatically changed over the past centuries. The first valuecreating compilation of the Slovak-American press was made by a well-known Slovak historian and journalist Konstantin Culen (1904-1964). In his work he agitated for the manifestation of Slovak cultural and national life in American and Canadian exile. His valuable publication, Slovak Magazines in America, was issued by The First Catholic Slovak Jednota in Cleveland, Ohio in 1970. Although some information lacks verification, the publication is considered one of the most authoritative works on this subject. The publication reflects the history of the first Slovak American press from 1898 to approximately 1962.

One of the most cited authors within this field of research is Marian Mark Stolarik, who was born in Slovakia but was 
evacuated to Canada in 1945. After earning his $\mathrm{PhD}$. degree at the University of Minnesota, he taught history at the Cleveland State University. From 1979 to 1991 he worked as the president and CEO of the Balch Institute for Ethnic Studies in Philadelphia. In 1992 M. M. Stolarik took up the position of a chairman in Slovak History and Culture at the University of Ottawa [4]. As an author and an editor of about eight books and sixty articles in professional journals, he is considered one of the most respected historians and researchers on Slovak-American exile. M. M. Stolarik completed the list of K. Culen's newspapers and magazines and added their demographic profile; and surveyed eleven kinds of periodicals published by Slovak-Americans from 1885 to 1984. His book "Where is My Home" [4] depicts the Slovak immigration to North America from 1870 to 2010.

The history shows that the Slovak and Czech communities had got together in order to protect their identities in the multinational melting pot of America. Therefore, it is important to mention at least some Czech editors of both Slovak and Czech exile. For example, Jozef Heller is the author of the publication "Cesky a Slovensky Tisk v Amerike do 1910" that was issued in a magazine "Svobodne skoly politickych nauk" in 1933. It is worth mentioning the work of Vladimír Pekelsky dealing with the Slovak exile press till 1958. The bibliographer and Czech-American compatriot, Esther Jerabek, provides a full inventory of published documentation on Slovak and Czechs in North America in her work "Czechs and Slovaks in North America" [9].

Czechoslovak archivalia and library holdings have been surveyed by the Czechoslovak Society of Arts and Sciences in cooperation with other international institutions in order to protect the Czech and Slovak cultural heritage abroad. As the result of this detailed survey (1999), the book, "Czechoslovak American Archivalia" [10] published in 2004. The author of the book is a respectful Czech historian Miloslav Rechcigl, Jr. who compiled both the Slovak but mostly Czech-related archival and library collections of all emigrant and exile groups and divided them into seven major categories:

- Government repositories;

- University-based collections;

- Collections maintained by public museums and libraries;

- Collections of ethnic organizations;

- Personal papers and collections;

- Repositories abroad bearing on the subject;

- Virtual archives and the internet [9].

One of the largest list of the Slovak archival material is kept in the Immigration History Research Center (IHRC) at the University of Minnesota, USA. The listings include approximately 850 books and pamphlets, 154 serial titles, 375 linear $\mathrm{ft}$ of manuscript material and 26 newspaper titles dated from 1893 to 1983. The work of M. Rechcigl, Jr. is extensive and represents a valuable source of information about the Czech but also on the Slovak immigrant work. However, the publication does not include current press activities of Slovak immigrants living in North America and does not provide a detailed form and content analysis of Slovak-American newspapers and magazines.

The first review of Slovak compatriot periodicals after 1989 was made by the Slovak Institute for the Study of Journalism in 1990. Their year-book provides a list of worldwide issued Slovak compatriot periodicals that are categorized by the country in which they are published. Their work mapped the overall situation of the Slovak compatriot press in the world, the USA included. The genre structure of the Slovak compatriot press issued in the USA was made by Maximilian Horansky [11] who provided brief and fragmental characteristics of the Slovak compatriot press, genre framework and orientation of each periodical that was published from 1989 to 1990.

One of the latest publications on the most famous and significant Slovak compatriot press was written by Pavol Holestiak in 2002 [7]. It provides brief and fragmental characteristics of the Slovak compatriot press, genre framework and orientation of each periodical that was published from 1989 to 1990 and an overall typology of the worldwide issued Slovak compatriot press in terms of their periodicity and location. The primary goal of his work was to give a complex review of Slovak immigrant press activities that include Europe, the USA and Canada from 1993 to 2000. Despite of valuable and rich work of the writers mentioned above, neither of them has made a detailed content analysis of at least one exile release issued in the USA. Similar research has not been made since the last survey made by P. Holestiak in 2002.

\section{Conclusions}

The idea of mapping the current situation of Slovak-American compatriot press has arisen in compliance with a policy concept of the Slovak Republic as well as other international organizations that deal with the cultural heritage preservation [12]. We have focused on the data collection by searching the internet to find the contact addresses of Slovak fraternal organizations and publishers mentioned in P. Holestiak's publications. We have looked up the web site of the Office for the Slovaks Living Abroad that gives to publicity the subsequent internet addresses:

- The National Slovak Society: www.nsslife.com;

- The First Catholic Slovak Union of the USA and Canada: www.fcsla.com;

- The Slovak Catholic Sokol: www.slovakcatholicsokol.org;

- The Slovak Garden: www.slovakgarden.com;

- The Slovak Institute: www.slovakinstitute.com;

- The Slovak Heritage and Folklore Society International: www.SlovakPride.homestead.com.

After analyzing the above mentioned web sites we contacted the societies by email. Most of the societies were willing to help and showed interest in our research. Eventually, we have come to 
the solution that the current situation of the Slovak compatriot press activities in the northern part of the USA are highly dependent on fraternal societies which work as the only editorial offices of the current compatriot press. We have come up with the sample that represents current electronic periodicals published in the North of the USA:

1. Jednota;

2. Slovak in America;

3. Slovak Catholic Falcon;

4. Fraternally Yours;

5. Floridian Slovak;

6. Slovak American Society of Washington Newsletter;

7. National News;

8. Youth Circle;
9. Wisconsin Slovak;

10. Slovakia;

11. Bridge;

12. The Morning Star;

13. The Zion.

Since the Internet represents a new form of media, almost all publishers of the Slovak-American press release their issues on their websites. This fact allowed us an easy access to the sample needed for our further research. What is more, the societies, including the editorial office of Slovaks in America, enable their members to keep in touch with them via Facebook as well. The Internet copies correspond to their paperback originals as they are still mailed to their subscribers.

\section{References}

[1] KLIMEKOVA, A.: Study of Foreign Slovakicist Documents [in Slovak]. Bibliograficky zbornik z 12. slovenskej bibliografickej konferencie, 2011. [online]. [cit. 2013-05-25]. Available on the internet: <http://www.snk.sk/swift_data/source/NBU/Zborniky/12_ BK/Klimekova.pdf>.

[2] CULEN, K.: The History of Slovaks in America [in Slovak], Bratislava : Slovenska Liga, 1942, 244 p.

[3] STOLARIK, M. M.: Immigration and Urbanisation, New York : AMS Press, 1989, 281 p.

[4] STOLARIK, M. M.: Where is My Home - Slovak Immigration to North America. Bern : Peter Lang, vol. 1, 2012, 392 p.

[5] BARTALSKA, L.: Cultural Heritage of the Slovaks Living Abroad and the Database of Information to the Issue [in Slovak]. Bratislava : Urad pre Slovakov zijucich v zahranici, 2008, $191 \mathrm{p}$.

[6] STOLARIK, M. M.: The Slovak American Press, New York - London : Greenmont Press, 1987, 18 p.

[7] HOLESTIAK, P.: Slovak Media in the World. Compatriotic Periodicals Abroad after the Restoration of Slovakia Autonomy [in Slovak], Cadca : Vzlet, 2002, $158 \mathrm{p}$.

[8] FRANKOVSKY, M., LAJCIN, D., SLAVIKOVA, G.: Social Intelligence as a Predictor of Managers Behaviour in Demanding Situations of Managerial Work, Management 2012: Research management and business in the light of practical needs, Presov : Bookman, 2012.

[9] JERABEK, E.: Czechs and Slovaks in North America, New York: Czechoslovak Society for Arts and Sciences in America, 1976, $448 \mathrm{p}$.

[10] RECHCIGL, M. JR.: Czechoslovak American Archivalia, Olomouc - Ostrava : Repronis, 2004, 204 p.

[11] HORANSKY, M.: Slovak Compatriot Periodicals [in Slovak], Bratislava : Novinarsky studijny ustav, 1990, 76 p.

[12] CABANOVA, V.: Family Library - Important Factor of Child Personality in a Family, J. of Interdisciplinary Philology, vol. 3, No. 2, 5-12, 2012. 